Journal of Advanced Research in Fluid Mechanics and Thermal Sciences

\title{
Simulation Influence of Compressor 3 Pressure and Cyclone Pressure on Specific Energy Consumption and Cooling Heat In Renewable Desalination
}

\author{
Engkos Achmad Kosasih ${ }^{1,}{ }^{*}$, Muhammad Irfan Dzaky ${ }^{1}$, Ahmad Zikri ${ }^{1}$, Ahmad Fadhil Nugraha $^{1}$ \\ 1 Department of Mechanical Engineering, Faculty of Engineering, Universitas Indonesia, Kampus UI Depok 16424, West Java, Indonesia
}

\begin{tabular}{|c|c|}
\hline ARTICLE INFO & ABSTRACT \\
\hline $\begin{array}{l}\text { Keywords: } \\
\text { Energy; Desalination; Compressor; } \\
\text { Aquadest; Cyclone Separator; } \\
\text { Refrigerant; Throttling }\end{array}$ & $\begin{array}{l}\text { The problem of freshwater is an issue that has been hot for discussion for decades. The } \\
\text { number of industries and the increasing population in the world has caused the need } \\
\text { for clean water to increase drastically. This scarcity occurs because } 97.7 \% \text { of the water } \\
\text { available on earth contains salt. Only } 2.3 \% \text { contains no salt, and } 99.5 \% \text { of the amount } \\
\text { is ice, groundwater, and the atmosphere. With a large percentage of seawater, water } \\
\text { needs for human survival can be met by using the desalination method. In this study } \\
\text { using a throttling valve and utilizing cold water (secondary product) as a refrigerant to } \\
\text { cool the room. This research will also discuss how specific energy consumption and } \\
\text { cooling heat are affected by compressor pressure and cyclone pressure to prove how } \\
\text { capable and efficient the renewable desalination method is in producing aquadest } \\
\text { water, which is expected to help water availability to meet water needs. The simulation } \\
\text { results obtained The optimum value of the system specific energy consumption is } \\
287.90 \mathrm{~kJ} / \mathrm{kg} \text { with a compressor pressure value of } 10 \mathrm{kPa} \text { and a cyclone temperature } \\
\text { value of } 4{ }^{\circ} \mathrm{C} \text {. The optimal value of system cooling heat is } 51.01 \mathrm{~kW} \text { with a compressor } \\
\text { pressure value. At } 10 \mathrm{kPa} \text { and a cyclone temperature value of } 2{ }^{\circ} \mathrm{C} \text {. The effect of the } \\
\text { cooling heat value significantly affects the specific energy consumption required for } \\
\text { this system. }\end{array}$ \\
\hline
\end{tabular}

\section{Introduction}

The high level of population development has caused a crisis in the availability of clean water. Many countries will consume water that has been desalinated [1]. This scarcity occurs because $97.7 \%$ of the water available on Earth contains salt. Only $2.3 \%$ do not contain salt, and even then, $99.5 \%$ of the amount is ice, groundwater, and atmosphere [2]. The percentage of seawater is higher when compared to the water requirements for humans. It's requires a process that can convert seawater into freshwater, one of which is the desalination method. Desalination is the process of separating a solution that has a lower concentration of dissolved salt (freshwater) and one that has a higher concentration of dissolved salt (brine) [3]. Water is critically important for human life. However, water demand is rapidly increasing due to population growth and uncontrolled human and industrial use. About eight and a half billion gallons/day of water are desalinated worldwide [4]. This number

\footnotetext{
${ }^{*}$ Corresponding author.

E-mail address: kosri@eng.ui.ac.id

https://doi.org/10.37934/arfmts.81.2.5966
} 
expects to continue to increase due to the increasing population and industry. The desalination process requires a large amount of energy, which is significantly higher than the energy requirements of conventional surface water treatment processes [5]. This energy is usually supplied both in the form of thermal and electrical energy. The energy-intensive nature of desalination processes places concomitant demand for energy sources as well. This situation can be termed as water for oil [6]. While energy needs for the desalination process can meet from various energy sources, many countries that lack water sources also lack conventional energy sources such as fossil fuels. This situation creates a need for efficient use of available energy sources for other profitable processes as well as a careful allocation of energy sources for freshwater production. This can be done by efficient process design, energy conservation, techno-economic utilization and analysis, and development of the systems under study. Although the first law of thermodynamics has been used easily to measure the energy efficiency of a process, it does not give an accurate measure of the efficiency of the process because the energy supplied to the system can never be recovered in its original quality. Energy converts into other forms in the process of utilization.

The thermoelectric process mostly generates the energy used in the desalination process. This process consumes a large amount of water for heat rejection to the thermodynamic cycle. It's estimated that about $15 \%$ of the water is evaporated in the cooling tower with the required power.

Shahzad et al., [7] demonstrated and demonstrated that the desalination process consumes only $2.75 \%$ of the primary exergy fuel in a combined cycle setting. They also said that for future sustainability, alternatives and new solutions are needed. Many scientists have researched a variety of desalination methods. Among them, seawater desalination technology utilizes microbial respiration [8]. There is also a seawater desalination technology that uses reverse osmosis methods [8]. But this technology harms the face of marine organisms and the environment. Kosasih et al., [9] also implements the process of strangling and using the remaining hot water from the condenser steam power plant so as not to damage the environmental ecosystem. To follow up on the research that has been done in producing water with the desalination method, this article will discuss the purification of seawater into freshwater using the renewable desalination method. Kosasih et al., [10] researched desalination systems by utilizing waste heat from a condenser steam power plant. The effect of pressure on distilled water production is quite significant. The increase in mass flow is directly proportional to the rise of aquadest production. The higher the mass flow rate, the greater the aquadest produced. The effect of tank water pressure is inversely related to specific energy consumption. Since they use a condenser steam power plant for their system, the specific energy consumption value can be negative $[11,12]$. This paper describes a simulation to produce aquadest. The method used is a thermodynamic simulation. The process in this research is an innovation by utilizing cold water from the cyclone separator. This cold water can be used to cool the room, and also the heat from cold water can be used in the condenser for the aquadest pre heater. The cold water functions as a refrigerant in the air conditioning system.

\section{Methodology}

In the simulation process of this research, there are three input parameters. Each is given a limitation as below.

(a) The heat exchanger outlet temperature 1 , minimum $50{ }^{\circ} \mathrm{C}$, and maximum $90{ }^{\circ} \mathrm{C}$ with an interval of $10^{\circ} \mathrm{C}$.

(b) The pressure of the cyclone separator is a function of the temperature. The minimum temperature value is $2^{\circ} \mathrm{C}$, and the maximum value is $4{ }^{\circ} \mathrm{C}$ (minimum value of the pressure is 
$0.705988 \mathrm{kPa}$, and the maximum value is $0.813549 \mathrm{kPa}$ ). Among the temperature values, inputs are given at intervals of $0.5^{\circ} \mathrm{C}$.

(c) The minimum value of the compressor 3 pressure is $10 \mathrm{kPa}$, and the maximum value is $50 \mathrm{kPa}$ with an interval of $10 \mathrm{kPa}$.

The simulation is using Microsoft Excel with ThermoTable Add-ins. Generally, the schematic diagram for the desalination system is shown in Figure 1. The water from the environment (seawater) will flow to the intercooler 1 and 2 before the pre-heating process. Then water continues to heat exchanger 1 to continue the pre-heating process. In the pre-heating process, the temperature of the seawater and its enthalpy will be increased. Next, the seawater through to the throttling valve and the flow to the cyclone separator. The throttling valve controls the pressure in the cyclone separator.

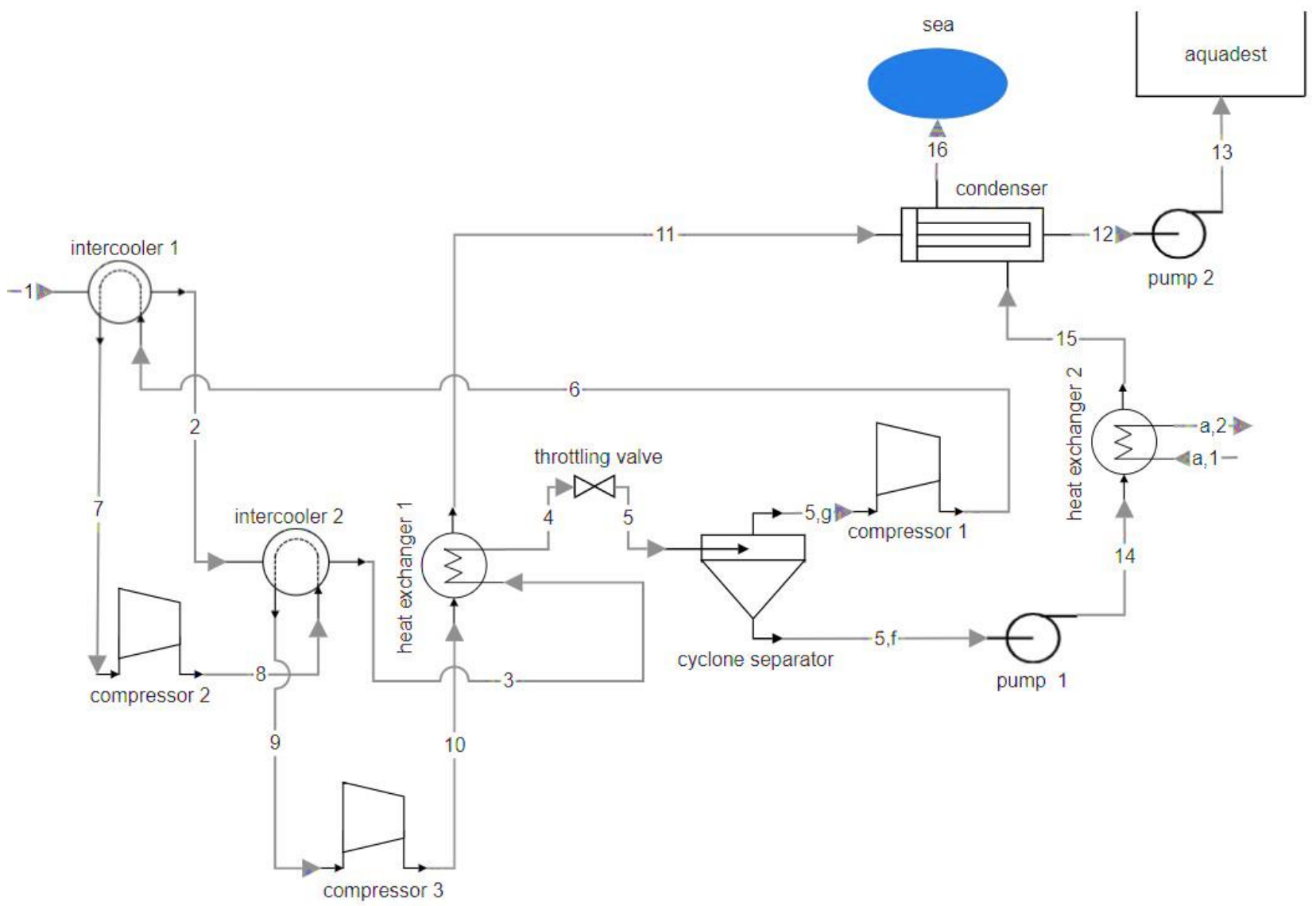

Fig. 1. Schematic Diagram of Desalination System

After reaching the desired pressure variable, the seawater is streamed to the cyclone separator. On this cyclone separator, vapor and water are separated. The water vapor compressed to the first compressor and passed the intercooler 1 to cooling down the water vapor. Then re-enters the second compressor to be compressed and re-enter the intercooler 2. On the compressor 3, the pressure variable is determined. The vapor from the compressor 3 is still at a high temperature. The high temperature from the compressor 3 will be utilized to raise the temperature of the seawater at the heat exchanger 1.

Water in the cyclone separator has a low temperature. Therefore, water with low temperature is used as an air conditioner refrigerant. The cooling process will occur in the heat exchanger 2 . At the end of the process, the low temperature of the water will be utilized to condensed water vapor in a condenser to produces aquadest. The water vapor that has condensed completely will be pumped into the aquadest shelter. Meanwhile, the water will be discharged back into the sea with a low 
temperature so as not to damage the surrounding ecosystem. Below is an explanation of the equation used for the theoretical calculations of the desalination systems.

In the pre-heating process, seawater will be flowed into intercooler 1, intercooler 2, and heat exchanger 1 and can be formulated as the equation below.

$C p_{\text {Water }}\left(T_{4}-T_{3}\right)=X_{\text {Vapor }}\left(h_{11}-h_{10}\right)$

$C p_{\text {Water }}\left(T_{2}-T_{1}\right)=X_{\text {Vapor }}\left(h_{7}-h_{6}\right)$

$C p_{\text {Water }}\left(T_{3}-T_{2}\right)=X_{\text {Vapor }}\left(h_{9}-h_{8}\right)$

$C p_{\text {water }}$ is a water-specific heat capacity at constant pressure. The values of $T_{1}, T_{2}, T_{3}$, dan $T_{4}$ are the temperature in units of ${ }^{\circ} \mathrm{C}$. The value of $\mathrm{T}_{4}$ is the temperature outlet of the heat exchanger 1, which is variated in value. The temperature of seawater inlet $\left(T_{1}\right)$ assumes $32{ }^{\circ} \mathrm{C}$. $\mathrm{X}_{\text {vapor }}$ is a vapor phase fraction of the steam. The value of the vapor phase fraction is the total value of mass flow being reduced by the liquid phase fraction. The ratio of the vapor phase fraction to the liquid phase is determined by the pressure in the cyclone separator.

After going through the throttling process, the water pressure will be drop $1 \mathrm{~atm}$. In the throttling process, the value of enthalpy when entering and exiting is the same. This condition can be stated in the following equation.

$h_{5}=h\left(1 \mathrm{~atm}, T_{4}\right)$

The pressure in the cyclone separator becomes a factor that changes the ratio between the fraction of the vapor and liquid phases. The equation for the vapor and liquid phase fractions can be written as follows

$h_{5}=X_{\text {Vapor }} \cdot h_{5, g}+\left(1-X_{\text {Vapor }}\right) \cdot h_{5, f}$

$h_{5, g}$ is a specific enthalpy for water vapor, the value of $h_{5, g}$ is the the function of $h_{g}$ (vapor enthalpy) as a function of cyclone separator pressure. while $h_{5, f}$ is a specific enthalpy for water, the value of $h_{5, f}$ is the function of $h_{f}$ (liquid enthalpy) as a function of cyclone separator pressure.

After the steam passes through the cyclone separator, it will be compressed to increase its pressure. The goal is that when the temperature is condensed, it doesn't need to be too high. In this desalination method, the compressor is combined with an intercooler so that the power required to run the compressor is not too high. The intercooler here gets cooling from the seawater process, which will be processed into aquadest. As a result of this intercooler, the compression ratio of the value can be written with the equation

$\left(\frac{p_{10}}{p_{c y c}}\right)^{1 / 3}=\frac{p_{10}}{p_{9}}=\frac{p_{8}}{p_{7}}=\frac{p_{6}}{p_{c y c}}=R_{k, N}$

$R_{k, N}$ is the compression ratio value. $N$ is the level of compression used so that in this case, 3 is used because it uses 3 compressors. All of the pressure values in the equation below will be used to find the enthalpy and entropy values needed to calculate the compressor power.

After obtaining all the values of enthalpy and entropy, the power of the compressor can be known by using equations 


$$
\begin{aligned}
& P_{\text {comp } 1}=X_{\text {Vapor }}\left(h_{6}-h_{5, g}\right) \\
& P_{\text {comp } 2}=X_{\text {Vapor }}\left(h_{8}-h_{7}\right) \\
& P_{\text {comp } 3}=X_{\text {Vapor }}\left(h_{10}-h_{9}\right)
\end{aligned}
$$

The value of cooling heat is one of the factors that determine the value of specific energy consumption. The cooling heat here is assumed as a magnitude to calculate how much heat is given to cool a room. The value of the cooling heat is assumed using equations.

$Q_{\text {cooling }}=\left(1-X_{\text {Vapor }}\right) \cdot C p_{\text {water }} \cdot\left(T_{15}-T_{14}\right)$

In the heat exchanger here, it is assumed to use heat exchangers, and the environmental air rises following the heat given by water (refrigerant).

The first pump on this system was used to drain water from a cyclone separator to a heat exchanger 2.

$$
\begin{aligned}
& P_{\text {pump } 1}=\left(1-X_{\text {Vapor }}\right) \cdot\left(h_{14}-h_{5, f}\right) \\
& P_{\text {pump } 2}=X_{\text {Vapor }}\left(h_{13}-h_{12}\right)
\end{aligned}
$$

The specific energy consumption (SEC) is an energy that is required per unit of mass to produce the aquadest. The specific energy consumption here also takes into account the energy given to cool the room as the excess of this desalination method. Assuming the COP value is worth 3.5, the SEC can be known through the following equation.

$S E C=\frac{\left(P_{\text {comp } 1}+P_{\text {comp } 2}+P_{\text {comp } 3}+P_{\text {pump } 1}+P_{\text {pump } 2}-\frac{Q_{\text {cooling }}}{\operatorname{COP}}\right)}{X_{\text {Vapor }}}$

\section{Results}

The data obtained from the simulation results are processed into two graphical categories. Figure 2 shows the graphs of compressor pressure and cyclone pressure at certain energy consumption. The specific energy consumption value is the total of all necessary power and heat supplied to cool the room per unit mass of flowing water. All of the charts vary between compressor pressure, cyclone pressure, and exit temperature of the first heat exchanger. On each graph, there are five curves where each curve shows the variation in cyclon pressure. The cyclone pressure here is indicated by temperature. This is done to make it easier to determine variations.

Figure 2(a), it can be seen that the value of specific energy consumption has an average of 508.45 $\mathrm{kJ} / \mathrm{kg}$. The minimum specific energy consumption value is $324.92 \mathrm{~kJ} / \mathrm{kg}$ by setting the compressor pressure of $10 \mathrm{kPa}$, and the cyclone temperature of $2{ }^{\circ} \mathrm{C}$. Meanwhile, the maximum specific energy consumption value is $639.10 \mathrm{~kJ} / \mathrm{kg}$ by setting the compressor pressure of $50 \mathrm{kPa}$, and a cyclone temperature of $4{ }^{\circ} \mathrm{C}$. The specific energy consumption values are seen to increase with cyclone pressure and compressor pressure. Figure 2(b), the specific energy consumption value indicated has an average value of $472.41 \mathrm{~kJ} / \mathrm{kg}$. The minimum specific energy consumption value is $287.90 \mathrm{~kJ} / \mathrm{kg}$ by setting the compressor pressure of $10 \mathrm{kPa}$, and the cyclone temperature of $4{ }^{\circ} \mathrm{C}$. Meanwhile, the 
maximum specific energy consumption value is $606.45 \mathrm{~kJ} / \mathrm{kg}$ by setting the compressor pressure of $50 \mathrm{kPa}$, and the cyclone temperature of $2^{\circ} \mathrm{C}$. The specific energy consumption value increases when the compressor pressure value also increases. However, the energy consumption value decreases when the cyclonic pressure value increases.

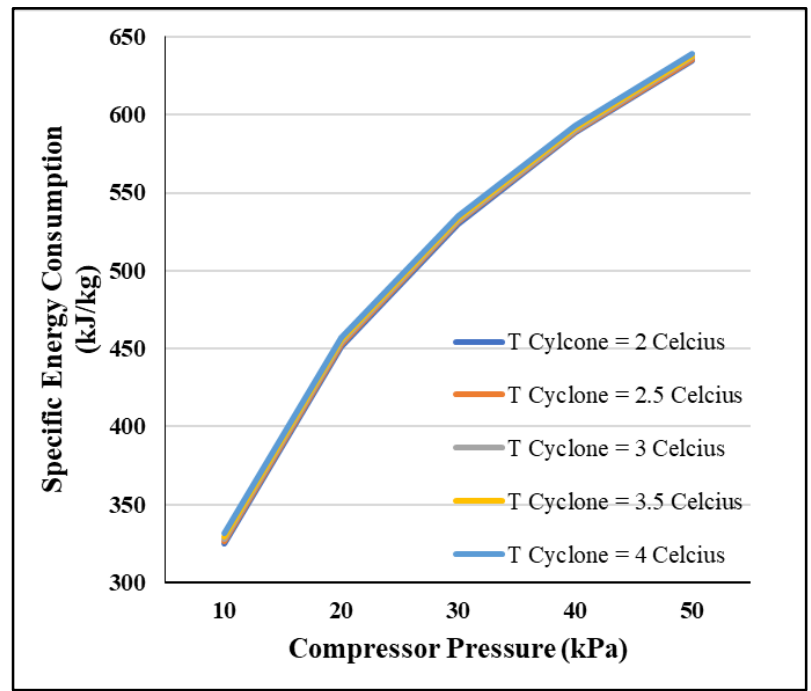

(a)

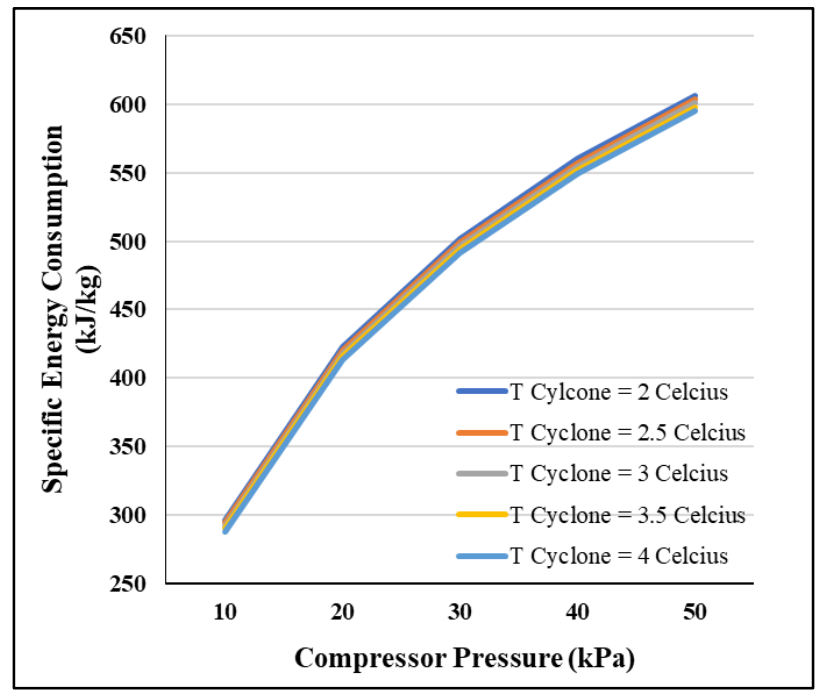

(b)

Fig. 2. (a) Graph of Specific Energy Consumption Changes to $3^{\text {rd }}$ Compressor Pressure and Cyclone Pressure at $\mathrm{T}_{4}=50^{\circ} \mathrm{C}$. (b) Graph of Specific Energy Consumption Changes to $3^{\text {rd }}$ Compressor Pressure and Cyclone Pressure at $\mathrm{T}_{4}=90^{\circ} \mathrm{C}$

It can be seen in the two graphs; the specific energy consumption value is always increased with the increase in the compressor pressure value. However, the specific energy consumption value decreases with the increase in the value of the cyclonic pressure. From all of these graphs, the lowest consumption value is $287.90 \mathrm{~kJ} / \mathrm{kg}$, and the highest is $639.10 \mathrm{~kJ} / \mathrm{kg}$. So, it can be concluded that the optimum value of this system is $287.90 \mathrm{~kJ} / \mathrm{kg}$, and the specific energy consumption value increases with the increase in the compressor pressure value and decreases with the increase in cyclone pressure and the first heat exchanger outlet temperature.

Figure 3 shows the effect of compressor pressure and cyclone pressure on cooling heat. The cooling calorific value is the heat provided by the system to cool the room. All of the above variations vary between compressor pressure, cyclone pressure, and exit temperature of the first heat exchanger. The $\mathrm{X}$-axis shows the compressor pressure in kilopascals, while the $\mathrm{Y}$-axis shows the value of cooling heat in kilowatts. On each graph, there are 5 curves where each curve shows the variation in cyclonic pressure. The cyclone pressure here is indicated by temperature. Figure 3(a) it can be seen that the heat value of the coolant has an average of $15.13 \mathrm{~kW}$. The minimum value of cooling heat is $10.41 \mathrm{~kW}$ by setting the compressor pressure of $50 \mathrm{kPa}$, and the cyclone temperature of $4{ }^{\circ} \mathrm{C}$. While the maximum cooling heat value is $20.10 \mathrm{~kW}$ with a compressor pressure of $10 \mathrm{kPa}$ and a cyclone temperature of $2{ }^{\circ} \mathrm{C}$. For each node, the value the cooling heat continues to decrease for the value of cyclone pressure and compressor pressure. Figure 3(b), it can be seen that the average cooling calorific value is $45.88 \mathrm{~kW}$. The minimum cooling heat value is $41.14 \mathrm{~kW}$ by setting the compressor pressure of $50 \mathrm{kPa}$, and the cyclone temperature of $4{ }^{\circ} \mathrm{C}$. While the maximum cooling heat value is $51.01 \mathrm{~kW}$ with a compressor pressure of $10 \mathrm{kPa}$ and a cyclone temperature of $2{ }^{\circ} \mathrm{C}$. For each node, the value the cooling heat continues to decrease for the value of cyclonic pressure and compressor pressure. Seen in Figure 3, the value of cooling heat always decreases with the value of cyclone pressure and stress. However, compared to the exit temperature of the first heat exchanger, the 
cooling rate always increases. The lowest cooling rate is $10.41 \mathrm{~kW}$ at a heat exchanger temperature of $50{ }^{\circ} \mathrm{C}$. While the highest cooling rate is $51.01 \mathrm{~kW}$ at a heat exchanger temperature of $90^{\circ} \mathrm{C}$. So that the value of the cooling rate increases when the heat exchanger temperature increases.

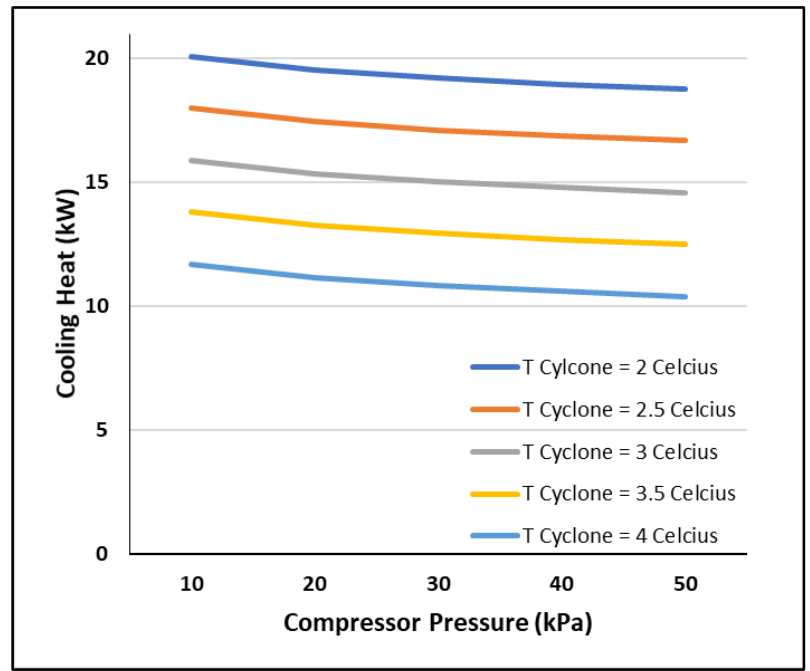

(a)

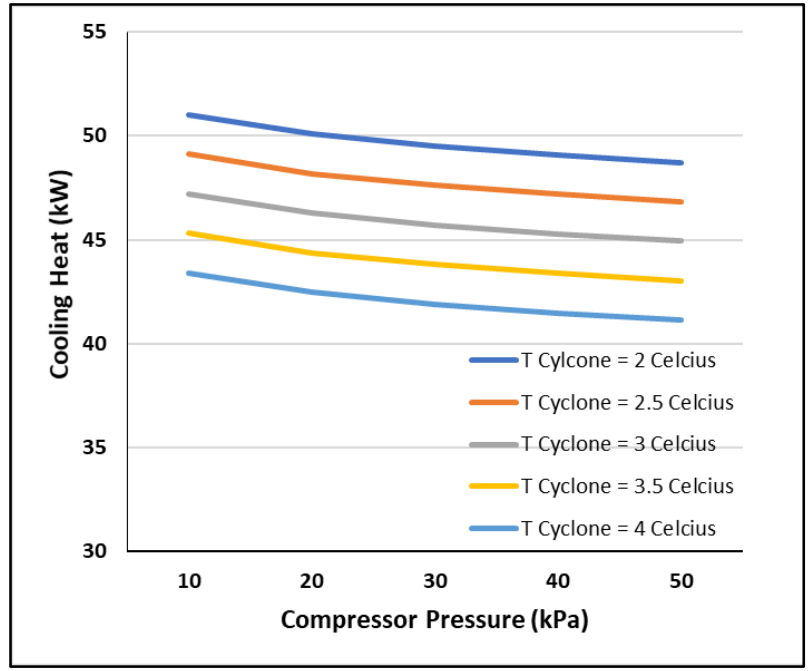

(b)

Fig. 3. (a) Graph of Cooling Heat Changes to $3^{\text {rd }}$ Compressor Pressure and Cyclone Pressure at $T_{4}=50^{\circ} \mathrm{C}$. (b) Graph of Cooling Heat Changes to $3^{\text {rd }}$ Compressor Pressure and Cyclone Pressure at $\mathrm{T}_{4}=90^{\circ} \mathrm{C}$

The optimal cooling heat value is at the compressor pressure value of $10 \mathrm{kPa}$, cyclone temperature of $2^{\circ} \mathrm{C}$, and the first heat exchanger temperature of $90^{\circ} \mathrm{C}$ of $51.01 \mathrm{~kW}$. The trend of changes in specific energy consumption is different from changes in the cooling rate. The change in specific energy consumption tends to increase as the compressor pressure value increases and decreases when the value of the cyclone pressure and the heat exchanger 1 heat outlet temperature increases. Whereas the cooling change tends to fall as the cyclonic and compressor pressure values increase, it increases with the increase in the first heat exchanger temperature value.

\section{Conclusions}

Overall, Based on the chapter results and the discussion, the desalination method can produce the aquadest with low energy consumption. The renewable desalination method can produce the aquadest and also cool the room by using cold water as a refrigerant. Cyclone pressure affects specific energy consumption and cooling heat. The higher the cyclone pressure then the required specific energy consumption tends to be lower, and the cooling heat is getting lower. The pressure of the compressor also affects the specific energy consumption and cooling heat. The higher the cyclone pressure then the required specific energy consumption is higher as well, but the cooling heat obtained is lower. The optimum value of the specific energy consumption is $287.90 \mathrm{~kJ} / \mathrm{kg}$ at a compressor pressure value of $10 \mathrm{kPa}$, and a cyclone temperature value of $4{ }^{\circ} \mathrm{C}$. The optimum value of the system cooling heat, is $51.01 \mathrm{~kW}$ at a compressor pressure value of $10 \mathrm{kPa}$ and a cyclone temperature value of $2^{\circ} \mathrm{C}$. The effect of the cooling heat value significantly affects the specific energy consumption required for this system. 


\section{Acknowledgement}

The authors would like to thanks to Universitas Indonesia for financial support through Hibah Publikasi Terindeks Internasional (PUTI) Prosiding 2020 under contract NKB1166/UN2.RST/HKP.05.00/2020.

\section{References}

[1] Escobar, Isabel C., and Andrea Schäfer, eds. "Sustainable water for the future: Water recycling versus desalination." Sustainability Science and Engineering, Volume 2, Elsevier, 2010.

[2] Kalogirou, Soteris A. "Seawater desalination using renewable energy sources." Progress in Energy and Combustion Science 31, no. 3 (2005): 242-281. https://doi.org/10.1016/i.pecs.2005.03.001

[3] Hamawand, Ihsan, Larry Lewis, Noreddine Ghaffour, and Jochen Bundschuh. "Desalination of salty water using vacuum spray dryer driven by solar energy." Desalination $404 \quad$ (2017): $182-191$. https://doi.org/10.1016/i.desal.2016.11.015

[4] Al-Karaghouli, Ali, David Renne, and Lawrence L. Kazmerski. "Solar and wind opportunities for water desalination in the Arab regions." Renewable and Sustainable Energy Reviews 13, no. 9 (2009): $2397-2407$. https://doi.org/10.1016/i.rser.2008.05.007

[5] Gude, Veera Gnaneswar. "Desalination and sustainability-an appraisal and current perspective." Water Research 89 (2016): 87-106. https://doi.org/10.1016/j.watres.2015.11.012

[6] Gude, Veera Gnaneswar. "Desalination of deep groundwater aquifers for freshwater supplies-Challenges and strategies." Groundwater for Sustainable Development 6 (2018): 87-92. https://doi.org/10.1016/j.gsd.2017.11.002

[7] Shahzad, Muhammad Wakil, Kim Choon Ng, Kyaw Thu, Bidyut Baran Saha, and Won Gee Chun. "Multi effect desalination and adsorption desalination (MEDAD): a hybrid desalination method." Applied Thermal Engineering 72, no. 2 (2014): 289-297. https://doi.org/10.1016/j.applthermaleng.2014.03.064

[8] Sevda, Surajbhan, Heyang Yuan, Zhen He, and Ibrahim M. Abu-Reesh. "Microbial desalination cells as a versatile technology: functions, optimization and prospective." Desalination $371 \quad$ (2015): 9-17. https://doi.org/10.1016/j.desal.2015.05.021

[9] Kosasih, Engkos Achmad, Ahmad Alfan Farizi, and Rizal Ibnu Wahid. "Aquadest Production System as Steam Turbine Bottom Cycle I: Influence of Pressure of Cooling Water Tank and Pinch Point Temperature Difference of Condenser." In E3S Web of Conferences, vol. 67, p. 04008. EDP Sciences, 2018. https://doi.org/10.1051/e3sconf/20186704008

[10] Kosasih, Engkos Achmad, Fauzan Widianto, Ahmad Alfan Farizi, and Rizal Ibnu Wahid. "Aquadest production system as steam turbine bottom cycle III: Influence of wastewater percentage and pinch point temperature difference of condenser." In AIP Conference Proceedings, vol. 2062, no. 1, p. 020001. AIP Publishing LLC, 2019. https://doi.org/10.1063/1.5086548

[11] Dzaky, Muhammad Irfan, Engkos Achmad Kosasih, Ahmad Zikri, Salsabil Dwikusuma Prasetyo, Muhammad Badra Shidqi, and Fakhri Rabbani Putranto. "The effect of water mass flow rate and pressure on specific energy consumption and aquades production using throttling process method." In AIP Conference Proceedings, vol. 2248, no. 1, p. 080003. AIP Publishing LLC, 2020. https://doi.org/10.1063/5.0013220

[12] Zikri, Ahmad, Engkos Achmad Kosasih, Muhammad Irfan Dzaky, and Muhammad Badra Shidqi. "Influence of water mass flow rate and water salinity on specific energy consumption and aquadest production using throttling process method." In AIP Conference Proceedings, vol. 2248, no. 1, p. 070004. AIP Publishing LLC, 2020. https://doi.org/10.1063/5.0013216 